\title{
MORPHOLOGICAL DEFORMITIES AND ATYPICAL COLOUR PATTERN IN THORNBACK RAY, RAJA CLAVATA (ELASMOBRANCHII: RAJIFORMES: RAJIDAE), FROM IZMIR (TURKEY, AEGEAN SEA, EASTERN MEDITERRANEAN)
}

\author{
Christian CAPAPÉ ${ }^{1}$, Ilker AYDIN ${ }^{2}$, and Okan AKYOL 2* \\ ${ }^{1}$ Laboratoire d'Ichtyologie, Université de Montpellier, Montpellier, France \\ ${ }^{2}$ Ege University, Faculty of Fisheries, Urla, Izmir, Turkey
}

Capapé C., Aydin I., Akyol O. 2018. Morphological deformities and atypical colour pattern in thornback ray, Raja clavata (Elasmobranchii: Rajiformes: Rajidae), from Izmir (Turkey, Aegean Sea, Eastern Mediterranean). Acta Ichthyol. Piscat. 48 (3): 261-266.

\begin{abstract}
Two specimens of the thornback ray, Raja clavata Linnaeus, 1758, from Turkish waters, exhibiting deformities of disc and tail are described in the present paper. One of these specimens had a colour pattern similar to type 7, vermiculated, it could constitute a transitional step between Raja clavata and its close relative species Raja maderensis Lowe, 1838.
\end{abstract}

Keywords: Rajidae, abnormalities, colour patterns, Turkish waters

\section{INTRODUCTION}

Thornback ray, Raja clavata Linnaeus, 1758, is known to occur along the eastern Atlantic coast, from Scandinavia, around the British Isles, France, and Portugal to the Strait of Gibraltar (Quéro et al. 2003). Further south, the species $R$. clavata is recorded off Morocco (Lloris and Rucabado 1998), Mauritania (Maurin and Bonnet 1970), and off the South African coast (Smith and Heemstra 1986). The thornback ray is also reported throughout the Mediterranean including the eastern areas (Golani et al. 2006), and it occurred in the Black Sea (Bilecenoğlu et al. 2014)

Raja clavata is distributed but not targeted in Turkish seas, and rather discarded at sea by fishermen. The species has low value and is not consumed locally, but it is sometimes exported to foreign countries such as Greece and United Kingdom. The total catch reached $116 \mathrm{t}$ in 2016, and the most abundant landings were reported from the Sea of Marmara (63\%), Aegean Sea (28\%), and Black Sea $(9 \%)$ (Anonymous 2017). Captures of thornback rays remained to be very rare in Izmir Bay (Aegean Sea), and during experimental trawl surveys carried out between 2006 and 2009, the total catch of $R$. clavata was only $3 \mathrm{~kg}$ from 116 hauls (Gurbet et al. 2013).

Investigations were conducted during a decade in Turkish waters focusing on elasmobranch species and constituted a larger research project. Some of the results of the project have already been published (Akyol and Capapé 2014, Akyol et al. 2017a, 2017b). Presently reported two $R$. clavata specimens, exhibiting tail abnormalities, were also a part of the above-mentioned project. The aim of this paper was to give a description of each specimen following Capapé et al. (2015a, 2015b) and comment on the origin of these atypical characteristics, and their role in the species growth.

\section{MATERIAL AND METHODS}

The first abnormal specimen of Raja clavata (Fig. 1) was caught on 30 September 2016, and a second (Fig. 2) on 7 February 2017; both at depths between 70 and $80 \mathrm{~m}$ by bottom trawl (44 $\mathrm{mm}$ mesh size in the cod end), off Cesme, Izmir $\left(38^{\circ} 25^{\prime} \mathrm{N}\right.$ and $\left.26^{\circ} 16^{\prime} \mathrm{E}\right)$. During the study, all absolute measurements were recorded to the nearest millimetre while all weights to the nearest gram. The absolute measurements were also expressed in relative values - as the percentage of the disc width (DW). The measurements and the meristic counts were performed following the methodology of Quignard (1965) and Stehmann (1970), except for trunchal vertebrae and pectoral rays counted based on X-ray photographs. The count of nictitating lamellae followed Capapé and Quignard (1981) and Mnasri et al. (2009a, 2009b). Morphometric measurements and meristic counts were summarized in Table 1, including also a normal specimen for comparison with the abnormal ones. Additionally, the relation between the disc width (DW) and the total body weight (TBW), was calculated including 39 normal specimens and both abnormal specimens, all collected in the same area. This relation is used to assess if the abnormal specimens are able to develop in the wild (Froese et al. (2011). Disc 
width was chosen as a reference character rather than total length, as recommended by Clark (1926) for studies concerning batoid species. This relation was expressed in decimal logarithmic scales and correlations were assessed by least-squares regression, to obtain a linear regression.
All specimens were delivered to the laboratory for subsequent study. Identification to the species level was performed based on Capapé and Desoutter (1981) and Stehmann and Bürkel (1984). The two abnormal specimens and the normal specimen (see Table 1) were preserved in
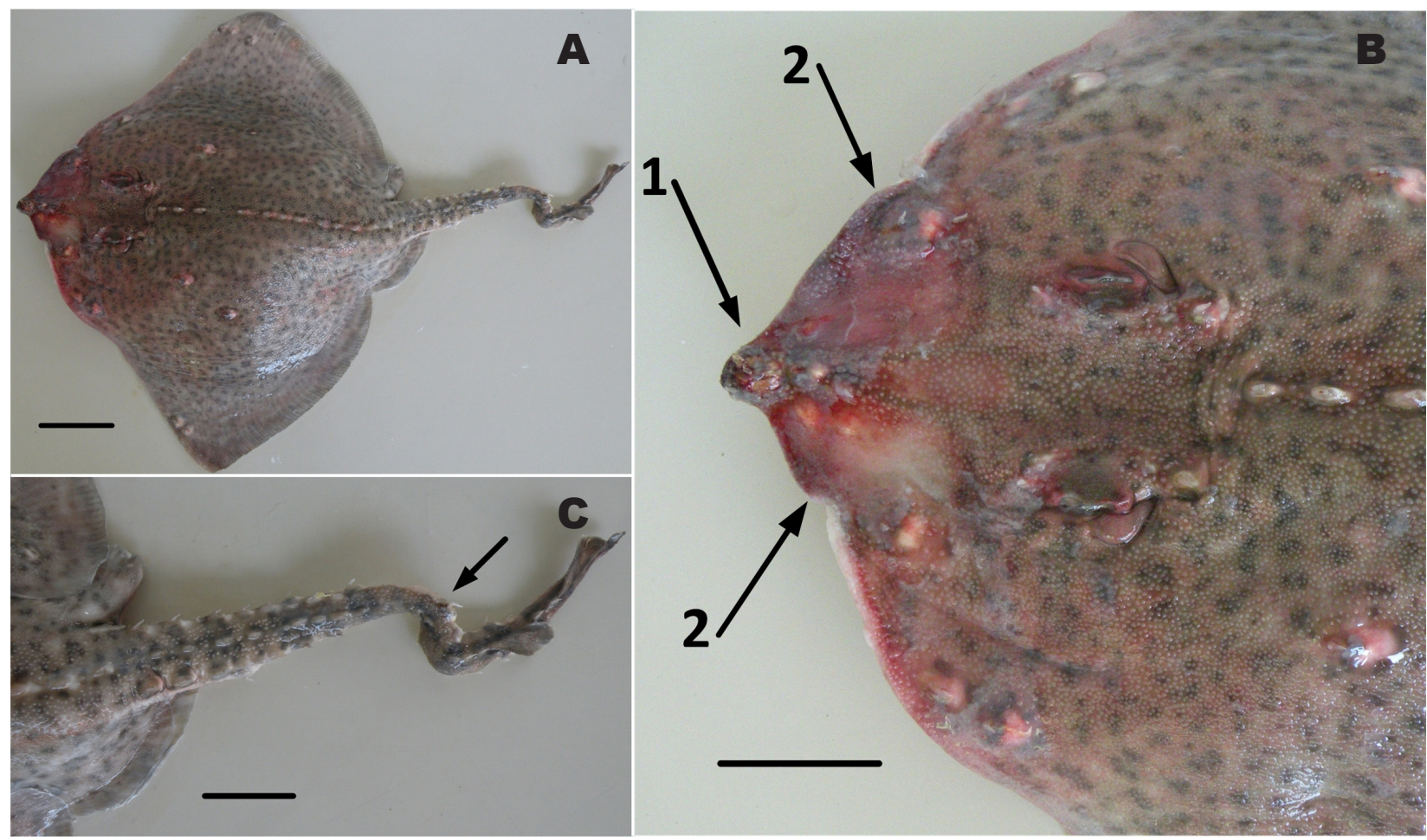

Fig. 1. A. Raja clavata (Ref. ESFM-PIS/2016-14), general morphology, scale bar $=50 \mathrm{~mm}$; B. Anterior region of the disc, with arrow 1 indicating snout and arrows $\mathbf{2}$ indicating notch on each side of the rostrum, scale bar $=50 \mathrm{~mm}$; C. Tail with arrow indicating the abnormality, $\mathrm{S}$ shape, scale bar $=50 \mathrm{~mm}$
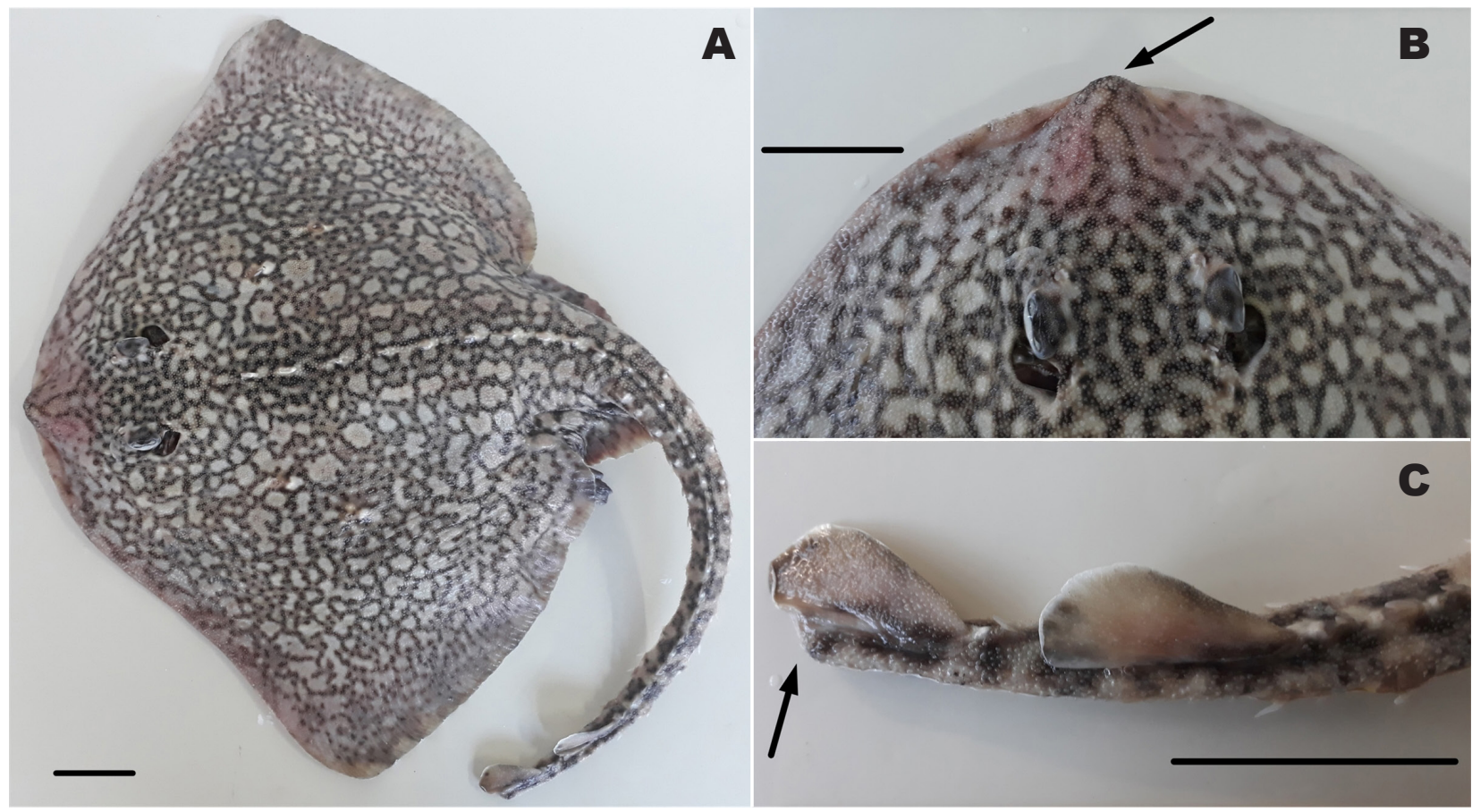

Fig. 2. A. Raja clavata (Ref. ESFM-PIS/2017-03), general morphology, scale bar $=50 \mathrm{~mm}$; B. Anterior region of the disc with arrow showing the reduced snout, scale bar $=50 \mathrm{~mm} ; \mathbf{C}$. Tail with arrow showing the lack of caudal fin, scale bar $=50 \mathrm{~mm}$ 
$5 \%$ buffered formalin and deposited in the Ichthyological left and the right side (Fig. 1A). The former was more Collection of Fisheries Faculty, Ege University, Turkey, sinuous and pointed in its distal end while than the latter receiving the catalogue numbers ESFM-PIS/2016-14, was rather rounded, especially in its distal end. The snout ESFM-PIS/2017-03, and ESFM-PIS/2018-02.

\section{RESULTS}

First abnormal specimen of Raja clavata (Ref. ESFM$\mathrm{mm}$ TL and weighed $3204 \mathrm{~g}$. It was an adult female (determined following Capapé et al. 2007). The general shape of the disc showed an asymmetry between the was conical and rounded, shorter than those observed in normal thornback rays (Fig. 1B). Both margins of the rostrum clearly showed a deformity, having the shape of a notch (Fig. 1B). It appears difficult to state about the origin of these deformities. The specimen was not entangled during its capture and therefore its deformity did not represent a healed scar, such as another specimen of $R$. clavata caught earlier in the area (Akyol and Aydin

Table 1

Absolute and relative morphometric measurements and meristic counts of two abnormal specimens and one normal specimen of Raja clavata collected from Turkish waters

\begin{tabular}{|c|c|c|c|c|c|c|}
\hline Catalogue number & \multicolumn{2}{|c|}{ ESFM-PIS/2016-14 } & \multicolumn{2}{|c|}{ ESFM-PIS/2017-03 } & \multicolumn{2}{|c|}{ ESFM-PIS/2018-02 } \\
\hline Total weight $[\mathrm{g}]$ & \multicolumn{2}{|c|}{3204} & \multicolumn{2}{|c|}{3411} & \multicolumn{2}{|c|}{405} \\
\hline Morphometric measurements & $\begin{array}{l}\text { ABS } \\
{[\mathrm{mm}]}\end{array}$ & $\begin{array}{c}\text { REL } \\
{[\% \mathrm{DW}]}\end{array}$ & $\begin{array}{l}\text { ABS } \\
{[\mathrm{mm}]}\end{array}$ & $\begin{array}{c}\text { REL } \\
{[\% \mathrm{DW}]}\end{array}$ & $\begin{array}{l}\text { ABS } \\
{[\mathrm{mm}]}\end{array}$ & $\begin{array}{c}\text { REL } \\
{[\% \mathrm{DW}]}\end{array}$ \\
\hline Total length & 670 & 137.0 & 730 & 140.4 & 435 & 151.0 \\
\hline Disk width (DW) & 489 & 100.0 & 520 & 100.0 & 288 & 100.0 \\
\hline Disk length & 311 & 63.6 & 363 & 69.8 & 211 & 73.2 \\
\hline Snout to nostril & 77 & 15.7 & 52 & 10.0 & 47 & 16.3 \\
\hline Snout to eye & 102 & 20.9 & 81 & 15.6 & 63 & 21.9 \\
\hline Snout to mouth & 86 & 17.6 & 82 & 15.8 & 59 & 20.5 \\
\hline Snout to first gill slit & 151 & 30.9 & 135 & 26.0 & 95 & 33.0 \\
\hline Snout to pectoral & 28 & 5.7 & 10 & 1.9 & 15 & 5.2 \\
\hline Anterior interspiracular width & 67 & 13.7 & 54 & 10.4 & 41 & 14.2 \\
\hline Spiracular length & 20 & 4.1 & 25 & 4.8 & 11 & 3.8 \\
\hline Internasal width & 63 & 12.9 & 63 & 12.1 & 37 & 12.8 \\
\hline Mouth width & 62 & 12.7 & 65 & 12.5 & 33 & 11.5 \\
\hline Pectoral fin anterior margin & 295 & 60.3 & 310 & 59.6 & 190 & 66.0 \\
\hline Pectoral fin posterior margin & 242 & 49.5 & 255 & 49.0 & 135 & 46.9 \\
\hline Pelvic fin anterior margin & 60 & 12.3 & 90 & 17.3 & 47 & 16.3 \\
\hline Pelvic fin posterior margin & 180 & 36.8 & 161 & 31.0 & 80 & 27.8 \\
\hline Eye diameter & 15 & 3.1 & 16 & 3.1 & 10 & 3.5 \\
\hline Tail length & 320 & 65.4 & 365 & 70.2 & 231 & 80.2 \\
\hline Snout to maximum width & 240 & 49.1 & 190 & 36.5 & 190 & 66.0 \\
\hline Interspiracular distance & 49 & 10.0 & 55 & 10.6 & 28 & 9.7 \\
\hline Prenasal length & 66 & 13.5 & 42 & 8.1 & 46 & 16.0 \\
\hline Internarial length & 60 & 12.3 & 61 & 11.7 & 37 & 12.8 \\
\hline Distance between first gill openings & 114 & 23.3 & 118 & 22.7 & 65 & 22.6 \\
\hline Distance between fifth gill openings & 65 & 13.3 & 60 & 11.5 & 35 & 12.2 \\
\hline Distance snout to cloaca & 345 & 70.6 & 344 & 66.2 & 189 & 65.6 \\
\hline Maximum distance between pelvic fins & 232 & 47.4 & 225 & 43.3 & 125 & 43.4 \\
\hline Distance cloaca to first dorsal fin & 252 & 51.5 & 295 & 56.7 & 160 & 55.6 \\
\hline Distance cloaca to second dorsal fin & 264 & 54.0 & 351 & 67.5 & 191 & 66.3 \\
\hline First dorsal fin base & 31 & 6.3 & 42 & 8.1 & 22 & 7.6 \\
\hline Second dorsal fin base & 32 & 6.5 & 31 & 6.0 & 21 & 7.3 \\
\hline Distance cloaca to caudal tip & 356 & 72.8 & 380 & 73.1 & 241 & 83.7 \\
\hline \multicolumn{7}{|c|}{ Meristic counts } \\
\hline Tooth rows & \multicolumn{2}{|c|}{$42 / 44$} & \multicolumn{2}{|c|}{$42 / 44$} & \multicolumn{2}{|c|}{$42 / 44$} \\
\hline Pectoral rays & \multicolumn{2}{|c|}{91} & \multicolumn{2}{|c|}{91} & \multicolumn{2}{|c|}{91} \\
\hline Pseudo-branchial lamellae & \multicolumn{2}{|c|}{14} & \multicolumn{2}{|c|}{14} & \multicolumn{2}{|c|}{13} \\
\hline Truncal vertebrae & \multicolumn{2}{|c|}{26} & \multicolumn{2}{|c|}{26} & \multicolumn{2}{|c|}{26} \\
\hline Nictitating lamellae & \multicolumn{2}{|c|}{11} & \multicolumn{2}{|c|}{11} & \multicolumn{2}{|c|}{-} \\
\hline
\end{tabular}

$\mathrm{ABS}=$ absolute measurement, $\mathrm{REL}=$ relative value of measurement expresses as percentage of disc width (DW). 
2018). The first specimen escaped from gill nets or was discarded at sea after capture by fishermen because of the lack of its commercial value locally. A genetic origin of the abnormality cannot be totally ruled out, however, due to the fact that each notch was symmetrically arranged in each margin of the rostrum. The tail did not extend the length of the disc, but slightly deviated to the right side and strongly convoluted in the distal region, forming a large $\mathrm{S}$ shape, and X-ray photograph showed that in this region the vertebrae fused and could not be individually distinguished (Fig. 1C). Conversely, both dorsal and caudal fins were present and complete. The origin of the tail deformity could be accidental, probably occurring during the early period of the specimen life in the wild, or an abnormal development resulting from a genetic reason. Second abnormal specimen of Raja clavata (Ref. ESFM-PIS/2017-03). The specimen measured $520 \mathrm{~mm}$ DW, $730 \mathrm{~mm}$ TL, and weighed $3411 \mathrm{~g}$. It was also an adult female (Fig. 2A). The general shape of the specimen did not show an abnormality, however, the snout was minute and reduced (Fig. 2B), and the caudal fin was lacking at the distal tip of the tail, no scar was visible and this character could be considered as an abnormality (Fig. 2C). Additionally, colour patterns of the dorsal surface were characteristic of type 7, vermiculated sensu Mnasri et al. (2009a), described as the colour of dorsal surface green covered with white spots, circles, half-moons or lunules forming vermiculations which extend to the edges of the disc. Such colour patterns are very similar to those from Madeira ray, Raja maderensis Lowe, 1838, according to Stehmann and Bürkel (1984).

\section{DISCUSSION}

Abnormalities of pectoral fins occur most frequently in batoid species (Ribeiro-Prado et al. 2008) and can reach up to $50 \%$ of cases (Orlov 2011). Such phenomenon is due to the fact that pectoral fins failed to fuse together in front of the head in the early development (Mnasri et al. 2010). The first specimen (Ref. ESFM-PIS/2016-14) exhibited a light asymmetry between left and right wing and evident notches on each site of the rostrum, constituting the first case known to date in skates.

Bensam (1965) noted that embryonic deformities could be caused by intrauterine pressure exerted by other embryos. Rajid species are oviparous and the embryonic development occurs in egg case laid by females, consequently the origin of pre-natal abnormalities would be related to mutation or other developmental irregularities, and the role of unfavourable conditions such as large exposure to pollutants cannot be totally ruled out (Ribeiro-Prado et al. 2008). The study area, Izmir Bay and its vicinity, has large harbours, ship dismantling areas (i.e., Aliaga coast), and Gediz River delta, therefore, a significant enrichment in trace metals in sediments is regularly reported (Kucuksezgin et al. 2006, Kucuksezgin 2009, Pazi et al. 2017). Additionally, trace metals can decrease the collagen synthesis, cause protoplasmic poisoning, and change the integrity of bones (Iguchi and Sano 1982, Jawad et al. 2017).
Loss of part or total tail due to injury is quite frequent especially in stingrays, but rather rare in skates (Templeman 1965, Mnasri et al. 2009b, Orlov 2011). However, it was difficult to state if such injury occurred recently or during the earlier life stages of the specimen. Conversely, the distal end of the second specimen (Ref. ESFM-PIS/2017-03), described in the present paper, did not exhibit a scar, so the lack of anal fins, was not the consequence of an injury and rather suggested a teratological case. Similar patterns could be taken into consideration about the tail abnormality observed in the first specimen (Ref. ESFM-PIS/2016-14).

Abnormalities of tail in skates species are rather rare, less than 4\% according to Orlov (2011), and few instances were recently reported (Mnasri et al. 2010, Capapé et al. 2015a, 2015b) In total accordance with Orlov (2011), the three specimens described herein were not considerably affected by loss and abnormalities of tail since did not affect their development and swimming activities, although percentages of tail lengths versus disc width are lower in abnormal specimens than in normal specimen (Table 1). It is well known that skates and rays generally use pectoral fins for locomotion. These observations are corroborated by the relation between the disc width and the total body weight, plotted in Fig. 3, which showed a positive allometry with $b=3.32$, indicating that abnormal specimens reached similar biological parameters that the normal ones. However, the risk of mortality was probably greater in such abnormal specimens than those presenting a tissue loss or abnormalities of tails and could explain why the former were relatively less observed than the latter.

The colour patterns of the second specimen (Ref. ESFM-PIS/2017-03), in our opinion, constitutes a new case of type 7, vermiculated sensu Mnasri et al. (2009a), and thus increases the difficulty to separate Raja clavata

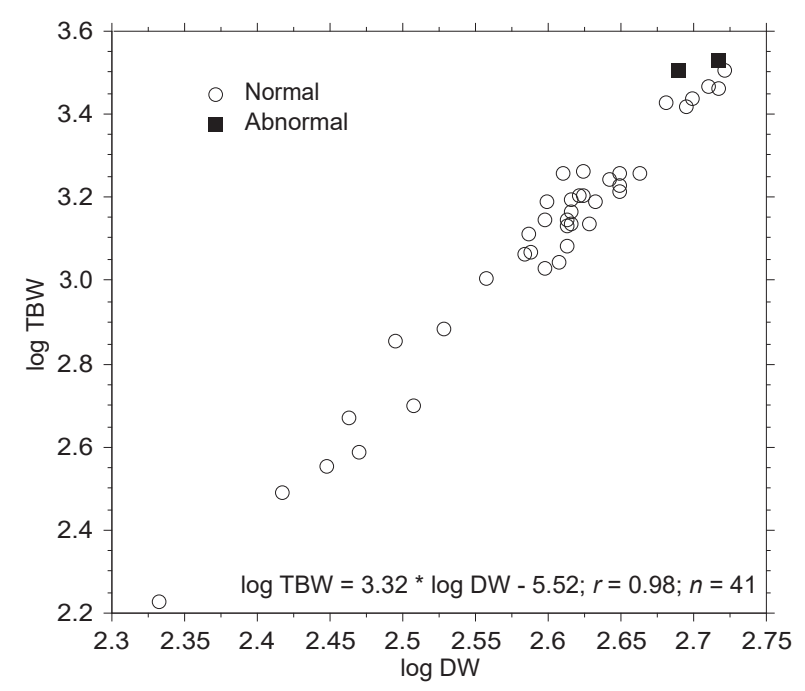

Fig. 3. Relation between the total body mass (TBM) and the disc width (DW) expressed in logarithmic scale for normal and abnormal specimens of Raja clavata collected from Turkish waters 
from $R$. maderensis. Ball et al. (2016) noted that genetic identification of specimens of $R$. maderensis and $R$. clavata was not sufficient to state about the fact that they are close but distinct species. The presently reported second specimen is closer to $R$. maderensis rather than $R$. clavata confirming the opinion of Ball et al. (2016) who noted that morphological differences between the two species are not in total accordance with the genetic distinctiveness. Following the opinion of Ball et al. (2016), type 7, vermiculated sensu Mnasri et al. (2009a), probably could be considered as a transitional "taxon" between Raja clavata and Raja maderensis.

\section{ACKNOWLEDGEMENTS}

The authors thank Captain Mustafa Taşlı and his crew of commercial trawler Yeni Asya for providing the specimens.

\section{REFERENCES}

Akyol A., Capapé C. 2014. Distribution of blackchin guitarfish Rhinobatos cemiculus E. Geoffroy SaintHilaire, 1817 (Elasmobranchii: Rhinobatidae) with first records from İzmir Bay (Turkey, northeastern Aegean Sea). Turkish Journal of Zoology 38 (4): 460465. DOI: $10.3906 /$ zoo-1307-32

Akyol O., Aydin I. 2018. Abnormal Raja clavata (Rajidae) in the Aegean Sea: A ghost fishing effect. Turkish Journal of Fisheries and Aquatic Sciences 18 (2): 357-358. DOI: 10.4194/1303-2712-v18_2_15

Akyol O., Aydın I., El Kamel-Moutalibi O., Capapé C. 2017a. Bull ray, Aetomylaeus bovinus (Geoffroy SaintHilaire, 1817) (Myliobatidae) in the Mediterranean Sea and captures of juveniles from Izmir Bay (Aegean Sea, Turkey). Journal of Applied Ichthyology 33 (6): 1200-1203. DOI: 10.1111/jai.13420

Akyol O., Aydın İ., Ulaş A., Capapé C. 2017b. On the capture of a large pregnant Bathytoshia lata (Chondrichthyes: Myliobatiformes: Dasyatidae) from the coast of Çeşme, Izmir (Aegean Sea, Turkey). Journal of the Black Sea/Mediterranean Environment 23 (1): 92-99.

Anonymous 2017. Su Ürünleri İstatistikleri. [Fishery statistics.] Türkiye İstatistik Kurumu. [Turkish Statistical Institute.] [Accessed on 7 December 2017.] http://www.tuik.gov.tr [In Turkish.]

Ball R.E., Serra-Pereira B., Ellis J., Genner M.J., Iglésias S., Johnson A.F., Jones C.S., Leslie R., Lewis J., Mariani S., Menzes G., Neal F., Noble L.R., Sims D.W., Griffiths A.M. 2016. Resolving taxonomic uncertainty in vulnerable elasmobranchs: Are Madeira skate (Raja maderensis) and the thornback ray (Raja clavata) distinct species? Conservation Genetic 17 (3): 565-576. DOI: 10.1007/s10592-015-0806-1

Bensam P. 1965. On a freak embryo of the grey-shark, Carcharhinus limbatus Müller and Henle. Journal of the Marine Biological Association of India 7 (1): 206-207.

Bilecenoğlu M., Kaya M., Cihangir B., Ciçek E. 2014. An updated checklist of the marine fishes of Turkey.
Turkish Journal of Zoology 38 (6): 901-929. DOI: 10.3906/zoo-1405-60

Capapé C., Ali M., Saad A., Alkusairy H., Reynaud C. 2015a. Atypical characteristics in the longnosed skate Dipturus oxyrhinchus (Linnaeus, 1785) from the coast of Syria (eastern Mediterranean). Thalassia Salentina 37: 71-80. DOI: 10.1285/i15910725v37p71

Capapé C., Ali M., Saad A., Reynaud C. 2015b. Tail abnormalities in thornback ray Raja clavata (Chondrichthyes: Rajidae) from the coast of Syria (eastern Mediterranean). Cahiers de Biologie Marine 56 (2): 155-161.

Capapé C., Desoutter M. 1981. Nouvelle description de Raja (Raja) clavata Linné, 1758 et note sur la validité de Raja (Raja) capensis Müller et Henlé, 1841. Cybium 5 (4): 23-39.

Capapé C., Guélorget O., Siau Y., Vergne Y., Quignard J.-P. 2007. Reproductive biology of the thornback ray Raja clavata (Chondrichthyes: Rajidae) from the coast of Languedoc (southern France, northern Mediterranean). Vie et Milieu 57 (1-2): 83-90.

Capapé C., Quignard J.P. 1981. A propos d'un caractère morphologique et méristique utile pour la détermination des Rajidæ. Rapports et procès-verbaux des réunions de la Commission internationale pour l'exploration scientifique de la mer Méditerranée 27 (5): 135-137.

Clark R.S. 1926. Rays and skates. A revision of the European species. Fisheries, Scotland, Scientific Investigations 1: 1-66.

Froese R., Tsikliras A.C., Stergiou K.I. 2011. Editorial note on weight-length relations of fishes. Acta Ichthyologica et Piscatoria 41 (4): 261-263. DOI: 10.3750/AIP2011.41.4.01

Golani D., Öztürk B., Başusta N. 2006. Fishes of the eastern Mediterranean. Turkish Marine Research Foundation, Publication No. 24, Istanbul, Turkey.

Gurbet R., Akyol O., Yalçın E., Özaydın O. 2013. Discards in bottom trawl fishery in the Aegean Sea (Izmir Bay, Turkey). Journal of Applied Ichthyology 29 (6): 1269-1274. DOI: 10.1111/jai.12243

Iguchi H., Sano S. 1982. Effect of cadmium on the bone collagen metabolism of rat. Toxicology and Applied Pharmacology 62 (1): 126-136. DOI: 10.1016/0041008X(82)90109-0

Jawad L., Akyol O., Sağlam C. 2017. Consecutive repetition of lordosis-kyphosis in silverside Atherina boyeri Risso, 1810 collected from a wild population in Homa Lagoon, Izmir, Turkey. Archive of Polish Fisheries 25 (2): 177122. DOI: 10.1515/aopf-2017-0011

Kucuksezgin F. 2009. Status of pollution in the Izmir Bay (eastern Aegean), 1996-2008: Nutrients, heavy metals and total hydrocarbon concentrations. Pp. 1-6. In: Impact of large coastal Mediterranean cities on marine ecosystems, 10-12 February 2009, Alexandria, Egypt.

Kucuksezgin F., Kontas A., Altay O., Uluturhan E., Darılmaz E. 2006. Assessment of marine pollution in Izmir Bay: Nutrient, heavy metal and total hydrocarbon concentrations. Environment International 32 (1): 4151. DOI: $10.1016 /$ j.envint.2005.04.007 
Lloris D., Rucabado J. 1998. Guide FAO d'identification des espèces pour les besoins de la pêche. Guide d'identification des ressources marines vivantes pour le Maroc. FAO, Rome.

Maurin, C., Bonnet M. 1970. Poissons des côtes nordouest africaines (Campagnes de la « Thalassa », 1962 et 1968). Revue des Travaux de l'Institut des Pêches Maritimes 34 (2): 125-170.

Mnasri N., Boumaïza M., Ben Amor M.M., Capapé C. 2009a. Polychromatism in thornback ray, Raja clavata (Chondrichthyes: Rajidae) off northern Tunisian coast (central Mediterranean). Pan-American Journal of Aquatic Sciences 4 (4): 572-579.

Mnasri N., Boumaïza M., Capapé C. 2009b. Morphological data, observations and occurrence of a rare skate, Leucoraja circularis (Chondrichthyes: Rajidae), off the northern coast of Tunisia (central Mediterranean). Pan-American Journal of Aquatic Sciences 4 (1): 70-78.

Mnasri N., El Kamel O., Boumaïza M., Ben Amor M.M., Reynaud C., Capapé C. 2010. Morphological abnormalities in two batoid species (Chondrichthyes) from northern Tunisian waters (central Mediterranean). Annales Series Historia Naturalis 20 (2): 181-190.

Orlov A.M. 2011. Record of a tailless Richardson's ray Bathyraja richardsoni (Garrick, 1961) (Rajiformes: Arhynchobatidae) caught off the Mid-Atlantic ridge. PanAmerican Journal of Aquatic Sciences 6 (3): 232-236.

Pazi I., Gonul L.T., Kucuksezgin F., Avaz G., Tolun L., Unluoglu A., Karaaslan Y., Gucver S.M., Orhon A.K., Siltu E., Olmez G. 2017. Potential risk assessment of metals in edible fish species for human consumption from the Eastern Aegean Sea.
Marine Pollution Bulletin 120 (1-2): 409-413. DOI: 10.1016/j.marpolbul.2017.05.004

Quéro J.C., Porché P., Vayne J.J. 2003. Guide des poissons de l'Atlantique européen. Les Guides du naturaliste. Delachaux \& Niestlé, Lonay (Switzerland) - Paris.

Quignard J.-P. 1965. Les raies du golfe du Lion. Nouvelle méthode de diagnose et d'étude biogéographique. Rapports et procès-verbaux des réunions de la Commission internationale pour l'exploration scientifique de la mer Méditerranée 18 (2): 211-212.

Ribeiro-Prado C.C., Oddone M.C., Bueno Gonzalez M.M., Ferreira de Amorim A., Capapé C. 2008. Morphological abnormalities in skates and rays (Chondrichthyes) from off southeastern Brazil. Arquivos de Ciencias do Mar, Fortaleza 41 (2): 21-28.

Smith M.C., Heemstra P.C. 1986. Smiths' sea fishes. Springer-Verlag edit, Berlin, Heidelberg, New York, London, Paris, Tokyo.

Stehmann M. 1970. Vergleichend morphologische und anatomische Untersuchungen zur Neuordnung der Systematik der nordostatlantischen Rajidae (Chondrichthyes, Batoidei). Archiv für Fischereiwissenschaft 21 (2): 73-164.

Stehmann M., Bürkel D.L. 1984. Rajidae. Pp. 163-196. In: Whitehead P.J.P., Bauchot, M.-L., Hureau J.-C., Nielsen J., Tortonese E. (eds.) Fishes of the Northwestern Atlantic and the Mediterranean. Volume 1. UNESCO, Paris.

Templeman W. 1965. Some abnormalities in skates (Raja) of the Newfoundland area. Journal of the Fisheries Research Board of Canada 22 (1): 237-238. DOI: $10.1139 / \mathrm{f} 65-023$

Received: 5 February 2018

Accepted: 7 June 2018

Published electronically: 30 September 2018 